\title{
Potential fish yield and physico-chemical characteristics of Weija reservoir in Ghana
}

\author{
T. QUARCOOPOME* \& R. ASMAH \\ (T. Q; R.A: CSIR-Water Research Institute, P. O. Box AH 38, Achimota, Ghana) \\ 'Corresponding author's email: qpome2@gmail.com
}

\begin{abstract}
The Weija Reservoir is an important resource for the production and supply of potable water, fish and irrigation services in Ghana. The study was undertaken to estimate the potential fish yield of Weija Reservoir to provide information for planning and management and to address the challenges of paucity of information on the potential fish yield of reservoirs in Ghana. Fish and water samples were collected monthly between March and December 2011 at Intake, Machigeni and Galilea sampling stations in the Weija Reservoir. Based on the physico-chemical parameters evaluated, the Weija Reservoir is adequate for fish survival, growth and production despite indications of low levels of organic contamination. Estimates of mean fish yield and potential fish yield for the three (3) stations based on morpho-edaphic index indicate that Machigeni has the highest yields followed by Intake and Galilea due to differences in anthropogenic activities, contamination and species richness. Monthly variations in potential fish yield and physico-chemical parameters follow similar pattern at all three sites with Machigeni recording the highest values and Intake the lowest. For the section of the reservoir sampled, the mean potential fish yield was $68.27 \mathrm{~kg} \mathrm{ha}^{-1}$ while the mean fish yield was $229.45 \mathrm{t} \mathrm{yr}^{-1}$ giving indication of declining fish yield compared to the earlier life of the reservoir which is attributable to physico-chemical, environmental, biological and anthropogenic changes. For successful fisheries management, regular monitoring of the fish species as well as control of fish habitat and environmental degradation are recommended.
\end{abstract}

Original scientific paper. Received 09 Aug 17; revised 24 Aug 18

\section{Introduction}

Reservoirs and lakes are important components of the modern aquatic ecosystem constituting an appreciable economic and environmental resource that provides numerous benefits to many countries, including Ghana. Reservoirs provide significant contributions to global fisheries (Fernando et al., 1988, Moreau \& De Silva, 1991, Miranda, 1999) and to fish production in several West African countries
(Dugan, 2003). The relative contribution of reservoirs to inland capture production may be even higher than officially reported (Kolding $\&$ van Zwieten, 2006) such as those ranging from 1,500 tonnes in Lake Manantali, Mali to between 40,000 and 215,000 tonnes in Lake Volta, Ghana (Lévêque, 1999, Braimah, 2000, 2003; Barry et al., 2005).

Fish provide the most available, affordable and preferred animal protein for many West

Ghana Jnl Agric. Sci. 53, 29 - 44

GJAS is an Open Access Journal and distributed under the terms of the Creative Commons (CC) License [CC BY 4.0] 
African communities and is a vital component of food security for many of the world's poorest people. In Ghana, the fisheries sector generates about $\$ 1$ billion per year and contributes $3 \%$ to annual Gross Domestic Product (GDP) and $4.5 \%$ to agricultural GDP and supports livelihoods of about $8-10 \%$ of the population (BOG, 2008). Yet there is an annual deficit of over $50.0 \%$ in fish requirements which is augmented by fish imports amounting to over $\$ 200$ million annually (BOG, 2008). Until aquaculture production is increased substantially to make up for the difference in annual fish requirement, there will be the need to depend on inland water bodies such as reservoirs for fish production.

Fish production in reservoirs is generally affected by morphological, physical, chemical and biological factors such as reservoir morphometry, physico-chemical characteristics, and phytoplankton. The techniques for predicting potential fish yield in lakes and reservoirs are very important to the development and management of freshwater fisheries especially in Africa and Southeast Asia. The most widely accepted method among several yield predictors in lakes and reservoirs is the morpho-edaphic index (MEI) developed by Ryder (1965). The simplicity of the MEI and its generally good and rapid predictive capabilities has resulted in its application worldwide. Howbeit, there are regional modifications such as in North American reservoirs (Jenkins, 1982), African lakes and reservoirs (Regier et al., 1971, Henderson \& Welcomme, 1974; Marshall, 1984; Adeniji, 1991; Kantoussan et al., 2007), temperate reservoirs (Schlesinger \& Reiger, 1982) and Asian reservoirs (Janjua et al., 2008).

This study was undertaken against the backdrop of limited information on the potential fish yield of reservoirs in Ghana coupled with changes in physico-chemical characteristics of inland waters over time due to anthropogenic, environmental, climatic and other factors. The objective of the study was to determine the potential fish yield of Weija Reservoir using the morpho-edaphic index (MEI) and physico-chemical parameters for management considerations.

\section{Materials and methods}

Study area

The Weija Dam is an earth fill embankment type with rock fill protection created on the River Densu in 1977 with dam height above river bed of $15.85 \mathrm{~m}$ and dam height above foundation of $18.90 \mathrm{~m}$. The Weija Reservoir $\left(0^{\circ} 20^{\prime}-0^{\circ} 25^{\prime} \mathrm{W}\right.$ and $\left.5^{\circ} 30^{\prime}-5^{\circ} 45^{\prime} \mathrm{N}\right)$ (Fig. 1) resulting from the damming of the River Densu at Weija is $14 \mathrm{~km}$ long and $2.2 \mathrm{~km}$ wide with a mean depth of $5.0 \mathrm{~m}$ (Vanden Bossche \& Bernacsek, 1990). Weija Reservoir is located about $17 \mathrm{~km}$ west of Accra and covers a surface area of approximately $33.61 \mathrm{~km}^{2}$ (3361 ha) of land at maximum water level. The reservoir area is low lying with undulating topography and isolated ridges. The Weija Reservoir has a storage volume of $116,040,000 \mathrm{~m}^{3}$. The normal retention water level is $14.37 \mathrm{~m}$ while the maximum flood water level is $15.24 \mathrm{~m}$. Weija Reservoir is one of the water production reservoirs in Ghana created to supply potable water to western parts of Accra. Additionally, the reservoir supports fisheries, which was one of the important activities that developed after impoundment.

Climatic conditions are tropical with wet season having moderate rainfall which peak in June and September with dry season spanning between December and March. Previous reports on Weija Reservoir include its physico-chemical characteristics, fish composition, fisheries and socio-economic status (Ameka et al., 2000; Ansa-Asare \& Asante, 1998; Dassah \& Abban, 1979; Abban, 1979; Balarin, 1988; 
Potential Fish yield \& Physico-Chemical Characteristics...

Ofori-Danson et al., 1993; Amevenku \& Quarcoopome, 2005; Quarcoopome \& Amevenku, 2006; Quarcoopome, 2010).

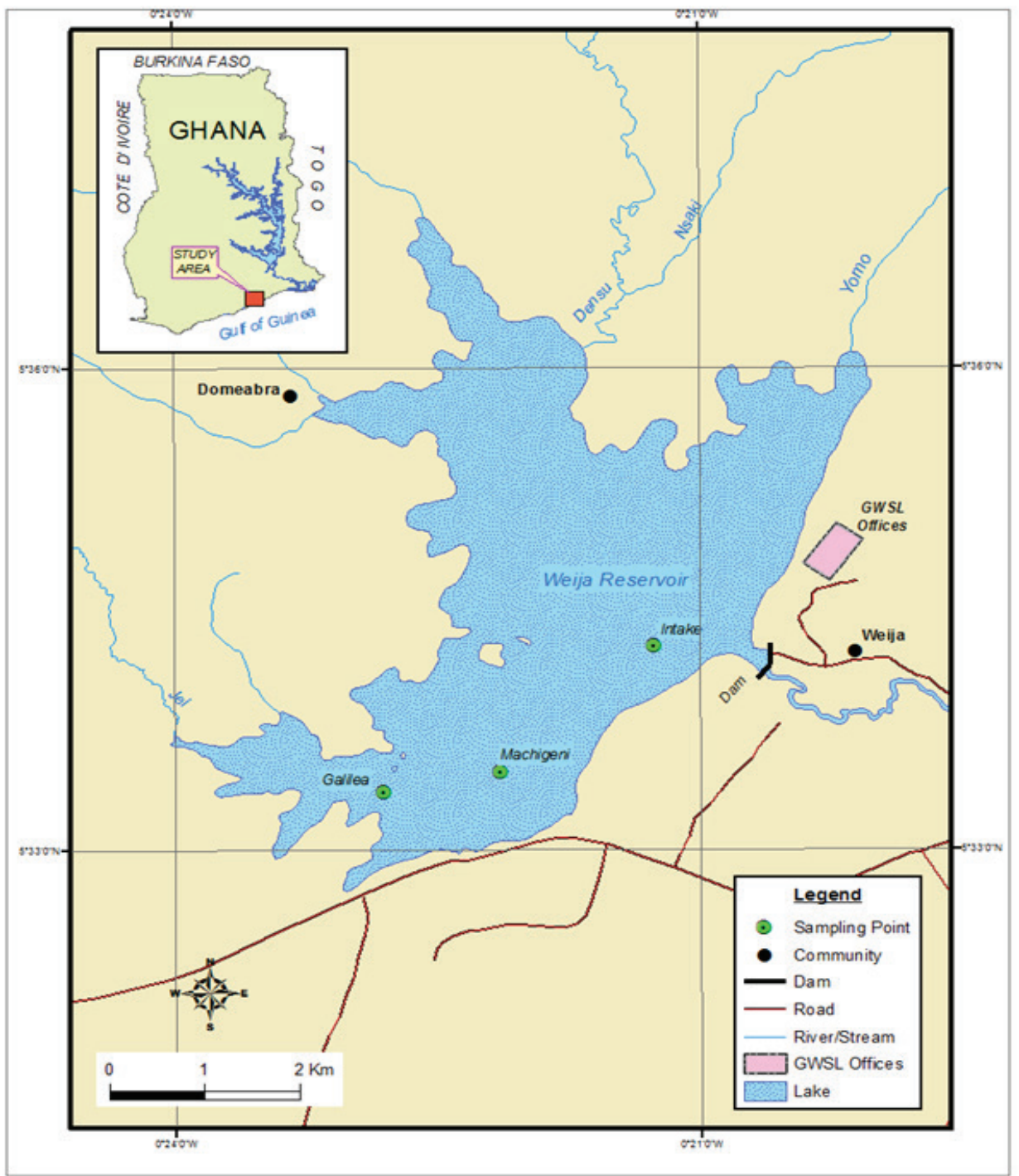

Fig. 1: Map of Weija Reservoir showing sampling stations

Reservoir classification

All man-made impoundments of size more than 10 hectares (ha) created by obstructing surface flow and erecting a dam of any description on a river, stream or any water course, have been reckoned as reservoirs (Sugunan, 1995). Reservoirs are classified generally as small $(<1,000$ ha), medium (1,000 to 5,000 ha) and large (> 5,000 ha) (Sarma, 1990; Srivastava et al., 1985). Generally, mean depths up to $7 \mathrm{~m}$ are 
considered low while those greater than $14 \mathrm{~m}$ are considered high.

\section{Data collection and analysis}

Samples of fish and water were taken monthly over a ten month period between March and December 2011 from three (3) previously sampled and easily accessible stations in the southern section of the Weija Reservoir.

\section{Physico-chemical parameters}

Surface water samples were collected from $1 \mathrm{~m}$ below the surface into pre-cleaned 1L Nalgene sample bottles using a Van-Dorn water sampler. Temperature, $\mathrm{pH}$, conductivity and dissolved oxygen were measured in situ (Table 1). All the collected samples were stored in insulated boxes with ice and transported to the CSIRWRI laboratories in Accra for analyses. The parameters determined include $\mathrm{pH}$, turbidity, conductivity, suspended solids (SS), total dissolved solids (TDS), alkalinity and total hardness. Major ions include cations namely calcium, potassium, sodium and magnesium as well as anions namely chloride, sulphate, fluoride and bicarbonate. Nutrients include ammonia, nitrate, nitrite, and phosphate. Other parameters were dissolved oxygen (DO) and biochemical oxygen demand (BOD). The physico-chemical parameters were determined according to the methods described in the Standard Methods for the Examination of Water and Wastewater (APHA-AWWA-WEF, 2005). The methods of analyses are listed in Table 1.

TABLE 1

Summary of Methods of Analyses

\begin{tabular}{ll}
\hline Parameter & Method of Analysis \\
\hline $\mathrm{pH}$ & $\mathrm{pH}$ Meter \\
Temperature & Temperature Probe \\
Conductivity & Cyberscan PC 510 \\
Turbidity & HACH 2100P Turbidimeter \\
Total Suspended Solids (TSS) & Gravimetric \\
Total Dissolved Solids (TDS) & Gravimetric \\
Dissolved Oxygen & Cyberscan DO 300 \\
Biological Oxygen Demand & Dilution Method \\
Chloride & Argentometric \\
Nitrate-nitrogen & Hydrazine reduction \\
Sulphate & Turbidimetric \\
Phosphate-phosphorus & Stannous Chloride \\
Total hardness & EDTA Titrimetric \\
Calcium & EDTA Titrimetric \\
Magnesium & EDTA - By Calculation \\
Sodium & JENWAY Flame Photometer \\
Potassium & JENWAY Flame Photometer \\
Iron & Flame AAS \\
Manganese & Flame AAS \\
\hline
\end{tabular}




\section{Fish}

Fish sampling was undertaken monthly in three previously sampled and easily accessible stations in the Weija Reservoir between March and December 2011. The type of nets used were multi-mesh multifilament $(12.5-40.0$ $\mathrm{mm})$ and monofilament (38.1 - $177.8 \mathrm{~mm})$ gill nets and were deployed overnight. Fish samples were identified and sorted according to species (Dankwa et al., 1999; Paugy et al., $2003 a, b)$. Each fish sample was weighed to the nearest $0.1 \mathrm{~g}$ using a mass balance and measured for standard length (SL) and total length (TL) to the nearest $1.0 \mathrm{~mm}$ and $0.1 \mathrm{~cm}$ respectively using a measuring board.

\section{Morpho-edaphic index (MEI)}

The MEI technique has gained recognition as a tool for predicting fish yield in lakes and reservoirs in all regions and for providing a rapid assessment of potential yield. The MEI is calculated by dividing the mean total dissolved solids or mean conductivity $\left(\mu \mathrm{S} \mathrm{cm} \mathrm{cm}^{-1}\right)$ by the mean depth $(\mathrm{m})$ of the water body as follows:

Depth (Ryder et al., 1974).

\section{Potential fish yield (PFY)}

The potential fish yield estimates were obtained using abiotic variables based on the chemical composition of the reservoir and the relationship:

$\mathrm{Y}=14.16 \mathrm{MEI}^{0.4581}$

(Henderson \&Welcomme, 1974)

Where $\mathrm{Y}$ is the potential fish yield in $\mathrm{kg} \mathrm{ha}^{-1}$ and MEI is Morpho-edaphic index expressed in $\mu \mathrm{S} \mathrm{cm}^{-1}$
Fish yield (FY)

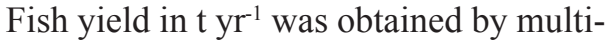
plying the potential fish yield in $\mathrm{kg} \mathrm{ha}^{-1}$ by the area of the reservoir in hectares and converting to tonnes per year.

\section{Results}

Physico-chemical parameters

Monthly variations in physico-chemical parameters at the three sampling locations are presented graphically in Figs 2 to 8 .

\section{Physical properties}

The $\mathrm{pH}$ of the reservoir ranged between 7.1 and 9.1 with the highest $\mathrm{pH}$ values at all the three sites being recorded in April and the lowest in August. Monthly changes in $\mathrm{pH}$ values followed a similar pattern at all the three sites (Fig. 2).

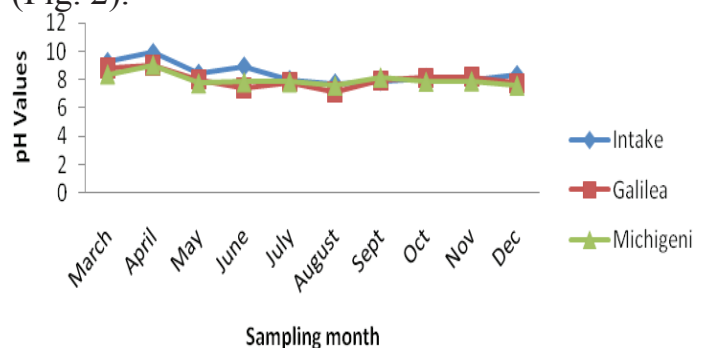

Fig. 2. Monthly variations in $\mathrm{pH}$ values at 3 Sampling stations in Weija Reservoir

Mean turbidity of the reservoir ranged from 5.64 NTU at Galilea to 42.9 NTU at the Intake point. Unlike $\mathrm{pH}$ where trends in $\mathrm{pH}$ values at the three sites followed a similar pattern, those for turbidity values were not consistent. Whilst the highest turbidity concentration at the Intake was recorded in March, those for Galilea and Machigeni were recorded in April and November respectively (Fig. 3). 


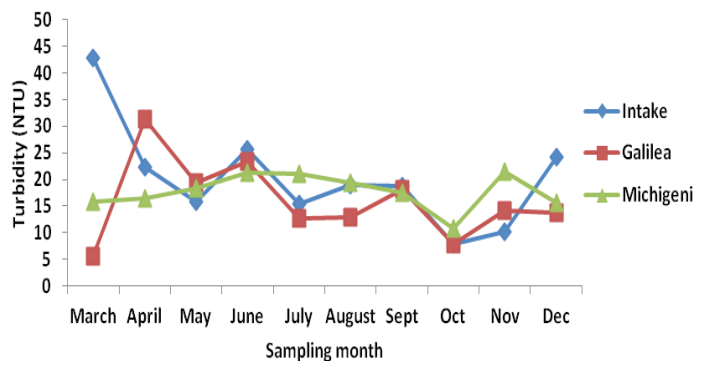

Fig. 3. Monthly variations in Turbidity at 3 Sampling stations in Weija Reservoir

The conductivity values at the three sites ranged between 366.2 and $421.5 \mu \mathrm{S} \mathrm{cm}^{-1}$ and were within the range 10 to $1,000 \mu \mathrm{S} \mathrm{cm}^{-1}$ expected for natural freshwater bodies. The highest mean conductivity was recorded at Machigeni and the lowest at the Intake point (Fig. 4). Total dissolved solids had a trend similar to that of conductivity as expected.

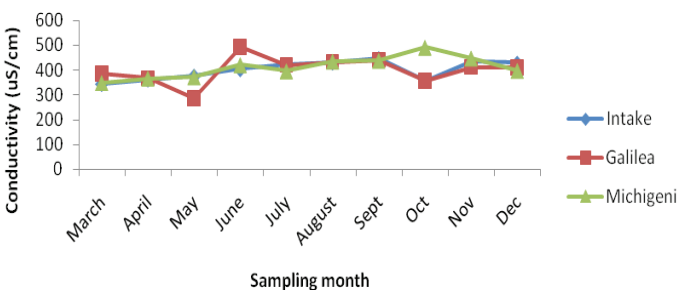

Fig. 4. Monthly variations in Conductivity at 3 Sampling stations in Weija Reservoir

\section{Major Ions}

The dominant cation at all these sites was sodium with a mean concentration range of 35.0 to $42.5 \mathrm{mg} \mathrm{l}^{-1}$ while the dominant anion was bicarbonate with a concentration range of 104.0 to $124.0 \mathrm{mg} \mathrm{l}^{-1}$. The general dominance pattern of the major cations was of the order $\mathrm{Na}>\mathrm{Ca}$ $>\mathrm{Mg}>\mathrm{K}$ whilst that for the anions was of the order $\mathrm{HCO}_{3}>\mathrm{Cl}>\mathrm{SO}_{4}$ (Fig. 5a, b).
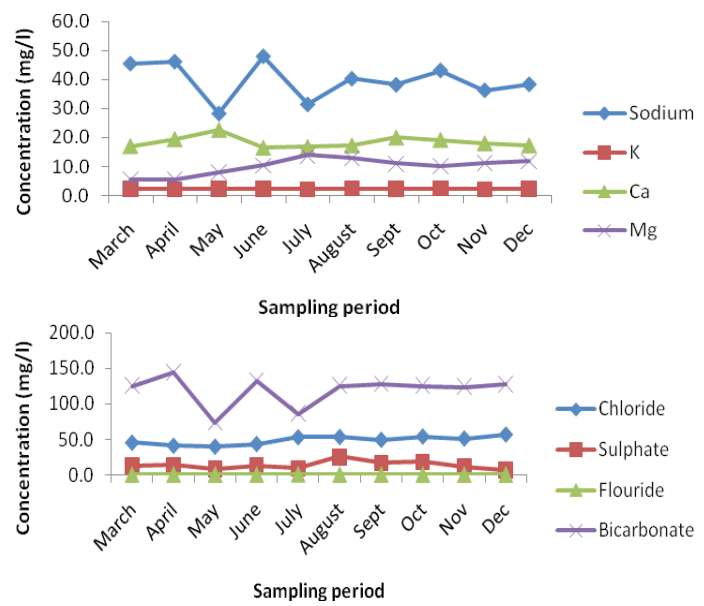

Fig. 5. a) Cationic and b) Anionic Dominance Pattern at 3 Sampling Stations in Weija Reservoir

\section{Nutrients}

There were very minimal variations in nutrient concentrations. Ammonia concentrations were the highest with mean concentrations at the three sites ranging from $1.1 \mathrm{mg} \mathrm{l}^{-1}$ to $1.2 \mathrm{mg}$ $1^{-1}$ (Fig. 6).

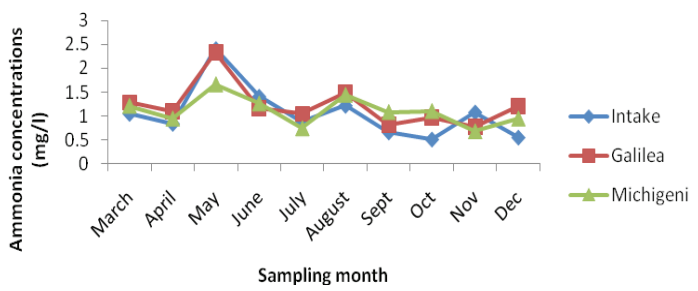

Fig. 6. Monthly variations in Ammonia at 3 Sampling stations in Weija Reservoir

Nitrate concentrations were the second highest after ammonia with mean values ranging from $0.30 \mathrm{mg} \mathrm{l}^{-1}$ at Machigeni to $0.50 \mathrm{mg} \mathrm{l}^{-1}$ at the Intake. Nitrite-nitrogen levels were the least of all the nutrients measured and this was because Nitrite-nitrogen concentrations in fresh wa- 
ter are normally very low, usually in the order of $0.001 \mathrm{mg} \mathrm{l}^{-1}$. The mean value of $0.1 \mathrm{mg} \mathrm{l}^{-1}$ observed at the sites, however, exceeded this value.

Mean Phosphate concentrations ranged from 0.10 to $0.20 \mathrm{mg} \mathrm{l}^{-1} \mathrm{PO}_{4}$-P and exceed concentrations in natural unpolluted waters, which range from 0.005 to $0.02 \mathrm{mg} \mathrm{l}^{-1}$.

\section{Dissolved Oxygen and Biochemical Oxygen Demand}

Dissolved Oxygen (DO) concentrations ranged from 7.2 to $10 \mathrm{mg} \mathrm{l}^{-1} ; 5.5$ to $8.1 \mathrm{mg} \mathrm{l}^{-1}$; and 3.1 to $9.7 \mathrm{mg} \mathrm{l}^{-1}$ at Intake, Machigeni and Galilea respectively. The highest mean DO was recorded at Intake (8.4 $\left.\mathrm{mg} \mathrm{l}^{-1}\right)$ with Machigeni (6.7 $\left.\mathrm{mg} \mathrm{l}^{-1}\right)$ and Galilea $\left(6.6 \mathrm{mg} \mathrm{l}^{-1}\right)$ following in that order. The individual concentrations were all above $5.0 \mathrm{mg} \mathrm{l}^{-1}$ except in October and December 2011 at Galilea where concentrations of 4.6 $\mathrm{mg} \mathrm{l}^{-1}$ and $3.1 \mathrm{mg} \mathrm{l}^{-1}$ were recorded respectively (Fig. 7). The BOD levels observed in the reservoir varied from $2.0 \mathrm{mg} \mathrm{l}^{-1}$ to $8.1 \mathrm{mg} \mathrm{l}^{-1}$. The lowest BOD concentrations were recorded at Machigeni with an overall mean value of 3.38 $\mathrm{mg}^{-1}$ (Fig. 8). Mean BOD values of $4.48 \mathrm{mg}$ $1^{-1}$ and $4.38 \mathrm{mg} \mathrm{l}^{-1}$ were recorded at the Intake and Galilea respectively.

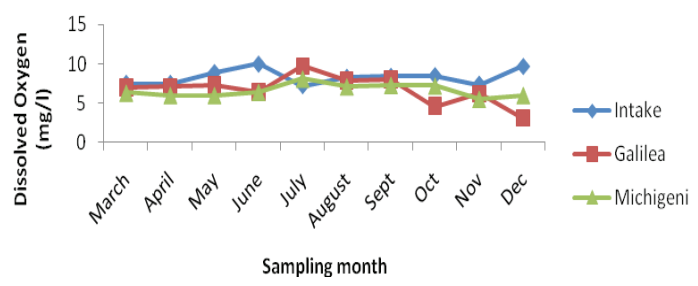

Fig. 7. Monthly Variation in Dissolved Oxygen at 3 Sampling Stations in Weija Reservoir

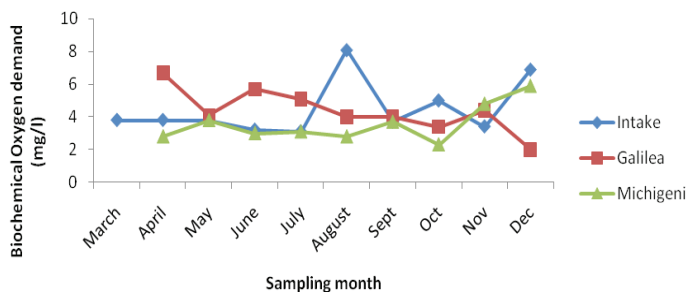

Fig. 8 Monthly Variation in BOD at 3 Sampling Stations in Weija Reservoir

Fish species composition

From Quarcoopome and Amevenku (2010), 17 fish species were sampled compared to 23 species prior to damming representing declining fish species in the Weija Reservoir.

\section{Potential fish yield}

Based on Henderson \& Welcomme (1974) the mean potential fish yield estimate for Machigeni was higher than that of Intake and Galilea in that order (Table 2). The mean potential fish yield for the southern section of the Weija Reservoir sampled was estimated at $68.27 \mathrm{~kg} \mathrm{ha}^{-1}$ (Table 2) which translates into fish yield of $229.45 \mathrm{t} \mathrm{yr}^{-1}$ (Table 3). Monthly variations in potential fish yield and fish yield follow similar patterns at all three sites with Machigeni recording the highest values and Intake the lowest (Table 2, 3). 
TABLE 2

Monthly Mean Potential Fish Yield (PFY) from 3 Stations on Weija Reservoir based on Morpho-edaphic Index (Henderson \& Welcomme, 1974)

\begin{tabular}{|c|c|c|c|c|c|c|c|c|c|c|c|}
\hline PFY Kg/ha & $\begin{array}{l}\text { March } \\
2011\end{array}$ & $\begin{array}{l}\text { April } \\
2011\end{array}$ & $\begin{array}{l}\text { May } \\
2011\end{array}$ & $\begin{array}{l}\text { June } \\
2011\end{array}$ & $\begin{array}{l}\text { July } \\
2011\end{array}$ & $\begin{array}{l}\text { August } \\
2011\end{array}$ & $\begin{array}{l}\text { September } \\
2011\end{array}$ & $\begin{array}{l}\text { October } \\
2011\end{array}$ & $\begin{array}{l}\text { November } \\
2011\end{array}$ & $\begin{array}{l}\text { December } \\
2011\end{array}$ & Mean \\
\hline Intake & 64.61 & 66.35 & 66.81 & 69.61 & 67.43 & 70.78 & 71.45 & 80.78 & 69.35 & 65.90 & 67.80 \\
\hline Galilea & 67.59 & 66.35 & 59.14 & 74.82 & 69.27 & 70.55 & 71.60 & 64.12 & 66.66 & 66.80 & 67.69 \\
\hline Machigeni & 64.61 & 66.35 & 66.81 & 69.61 & 67.43 & 70.78 & 71.45 & 80.78 & 69.35 & 65.90 & 69.31 \\
\hline Mean & 65.60 & 66.35 & 64.25 & 71.35 & 68.04 & 70.70 & 71.50 & 75.23 & 68.45 & 66.20 & 68.27 \\
\hline
\end{tabular}

TABLE 3

Monthly Mean Fish Yield (FY) from 3 Stations on Weija Reservoir based on

Morpho-edaphic Index (Henderson \& Welcomme, 1974)

\begin{tabular}{|c|c|c|c|c|c|c|c|c|c|c|c|}
\hline $\mathrm{FY} t / \mathrm{yr}$ & $\begin{array}{l}\text { March } \\
2011 \\
\end{array}$ & $\begin{array}{l}\text { April } \\
2011 \\
\end{array}$ & $\begin{array}{l}\text { May } \\
2011\end{array}$ & $\begin{array}{l}\text { June } \\
2011 \\
\end{array}$ & $\begin{array}{l}\text { July } \\
2011\end{array}$ & $\begin{array}{l}\text { August } \\
2011 \\
\end{array}$ & $\begin{array}{l}\text { September } \\
2011\end{array}$ & $\begin{array}{l}\text { October } \\
2011\end{array}$ & $\begin{array}{l}\text { November } \\
2011 \\
\end{array}$ & $\begin{array}{l}\text { December } \\
2011 \\
\end{array}$ & Mean \\
\hline Intake & 215.73 & 221.62 & 225.39 & 229.57 & 233.32 & 236.88 & 242.13 & 215.52 & 229.72 & 228.99 & 227.89 \\
\hline Galilea & 227.15 & 223.01 & 198.76 & 251.49 & 232.81 & 237.13 & 240.64 & 215.52 & 224.06 & 224.53 & 227.51 \\
\hline Machigeni & 217.16 & 223.01 & 224.56 & 233.95 & 226.62 & 237.89 & 240.13 & 271.51 & 233.08 & 221.49 & 232.94 \\
\hline Mean & 220.02 & 222.55 & 216.24 & 238.34 & 230.92 & 237.3 & 240.97 & 234.18 & 228.95 & 225 & 229.45 \\
\hline
\end{tabular}

TABLE 4

Correlation of Physico-chemical Parameters with Potential Fish Yield (PFY)

and Fish Yield (FY) Estimates for Weija Reservoir

\begin{tabular}{|c|c|c|c|c|c|c|c|c|c|c|c|}
\hline Parameter & SS & $T D S$ & $M g$ & Nitrite & Nitrate & Alkalinity & Mg hardness & Fluoride & Bicarbonate & $B O D$ & Iron \\
\hline $\mathrm{PFY} \mathrm{Kg/ha}$ & 0.34 & 0.89 & 0.98 & -0.51 & -0.98 & 0.71 & 0.99 & -0.56 & 0.71 & -0.97 & -0.92 \\
\hline $\mathrm{FY} \mathrm{t/yr}$ & 0.91 & 0.95 & 0.51 & -0.98 & -0.55 & 0.99 & 0.74 & -0.98 & 0.99 & -0.50 & -0.36 \\
\hline
\end{tabular}

\section{Discussion}

Reservoir classification

Going by the classification of Sarma (1990), and Srivastava et al. (1985), the Weija Reservoir can be described as medium-sized because it has a surface area of 3361 ha which falls within the $1000-5000$ ha range which is categorized as medium. Mean depths below $7 \mathrm{~m}$ are considered low and, therefore, on that basis the Weija Reservoir can be described as being of low depth.

\section{Physico-chemical factors}

The $\mathrm{pH}$ of natural waters is considered as an index of environmental conditions which affects the biochemical reactions and controls the activities and distribution of aquatic fauna and flora (Sugunan, 1995; Sharma, 2000). The $\mathrm{pH}$ of the reservoir was moderately alkaline (7.1 to 9.1 ) with minimal variation and within the $\mathrm{pH}$ range of 6.0 to 9.5 for most natural waters (Chapman 1996). This is an indication of the suitability of the reservoir for fish growth, sustenance and survival. The highest and lowest $\mathrm{pH}$ values at all the three sites were recorded in April and August, which are within the major and minor rainy seasons in southern Ghana respectively.

Oxygen is very important and essential for the growth and survival of fish because it affects fish respiration as well as nitrite and 
ammonia toxicity. Where DO concentration reduces, respiration and feeding activities decrease (Mallya, 2007) and fish are not able to assimilate food consumed (Tom, 1998) resulting in decreased growth rate and poor condition. DO is also an important measure of aquatic health with healthy water bodies usually having DO levels of $8 \mathrm{mg} \mathrm{l}^{-1}$ or higher. According to Boyd (1982), DO level should be at least $5 \mathrm{mg}$ $1^{-1}$ for a productive water body. Based on mean dissolved oxygen concentrations, the reservoir can be said to be well oxygenated and productive, thus suitable for fish survival, growth and reproduction.

The observed dominance pattern of the major ions in the Weija Reservoir did not conform to the ionic dominance pattern of $\mathrm{Ca}>$ $\mathrm{Mg}>\mathrm{Na}>\mathrm{K}$ for cations and $\mathrm{HCO}_{3}>\mathrm{SO}_{4}>\mathrm{Cl}$ $>\mathrm{F}$ for anions in freshwater. The dominance of $\mathrm{Na}$ over $\mathrm{Ca}$ in this study was attributed to human activities in the area and the influence of seawater since the area falls within the coastal zone. The mean concentrations of $\mathrm{K}$ remained unchanged over the period of sampling. This is probably because, as observed in this study, it is usually the least of the four elements which together constitute the major total cationic concentration in surface water (Talling, 2010).

The conductivity of water is a measure of the concentration of dissolved ions in solution. It is known that the higher the concentration of dissolved ions in water, the higher the conductivity of the water. The conductivity of the Weija Reservoir water can be said to be moderately high considering that conductivity levels above $200 \mu \mathrm{S} \mathrm{cm}^{-1}$ are considered optimal and good criteria for fish production (Das et al., 2008). Also, the conductivity level of the reservoir can be said to be high when compared with what pertains in other reservoirs in the country and sub-region of West Africa (Elegbede et al., 2015; Idowu et al., 2004). Overall, the conductivity of the Weija Reservoir is suitable for fish survival, growth and sustainability and also accounts for the high potential fish yield of the reservoir.

Turbidity of water influences the depth to which light is transmitted through the water column and is, therefore, a limiting factor for light penetration. This in turn controls the amount of primary productivity that is possible by controlling the rate of photosynthesis of algae present. Thus, increased turbidity is a major constraint on primary production and potential fish yield (Ofori-Danson \& Ntow, 2005).

Factors such as increased stream flow due to heavy rains can enhance turbidity by transporting suspended particles, such as clay and silt, to the water bodies. No clear variations were, however, observed at the sampling sites between the wet (April to June and September to November) and dry seasons (December to March and July to August). The lack of distinct trends between the seasons could be due to the fact that the origin and intra- and interannual variability of turbidity is not always well understood (Cooper et al., 2016). High turbidity in reservoirs may negatively affect aquatic ecology and water infrastructure.

The concentration of total dissolved solids (TDS) has been considered as an index of productivity of the aquatic environment (Jhingran, 1991). Rawat (1991) observed a significant relationship between total dissolved solids and quantities of plankton, bottom fauna and fish fauna. According to the criteria by Sreenivasan (1978), reservoirs with TDS of $50 \mathrm{mg} \mathrm{l}^{-1}$ are productive. Thus with TDS ranges of 189.0 $-238.0 \mathrm{mg} \mathrm{l}^{-1}$ at Intake, $196.0-271.0 \mathrm{mg} \mathrm{l}^{-1}$ at Galilea, and $192.0-325.0 \mathrm{mg} \mathrm{l}^{-1}$ at Machigeni the section of the water system in Weija Reservoir sampled is productive. Mean TDS values 
recorded at each station and for the sampled section of the reservoir (217.42) were higher than that observed in most medium and/or shallow reservoirs in Ghana and Nigeria and twice that for Oyun Reservoir in Nigeria (Mustapha, 2009) indicating high ionic content. The high ionic content could be due to weathering of underlying rocks and soil, runoffs from surrounding water, and high rainfall which carries most of the dissolved salts into the reservoir as well as anthropogenic factors such as construction and stone quarrying activities in the immediate environs of the reservoir.

Generally, there were very minimal variations in nutrient concentrations. Ammonia concentrations were the highest with mean concentrations at the three sites ranging between $1.1 \mathrm{mg} \mathrm{l}^{-1}$ and $1.2 \mathrm{mg}^{-1}$ followed by nitrates with mean values ranging from $0.30 \mathrm{mg} \mathrm{l}^{-1}$ to $0.50 \mathrm{mg} \mathrm{l}^{-1}$ while nitrites with mean value of $0.1 \mathrm{mg} \mathrm{l}^{-1}$ observed at the sites exceeded the normal value which is in the order of $0.001 \mathrm{mg}$ $1^{-1}$. Ammonium concentration observed at the sampling sites far exceeded concentrations in unpolluted waters which is normally less than $0.1 \mathrm{mg} \mathrm{l}^{-1}$ but may occasionally reach $0.2 \mathrm{mg}$ $1^{-1}$ (Chapman, 1996). Thus, giving indications of organic pollution from domestic sewage, industrial wastes and fertilizer run-off from agricultural activities which has cost implications for treatment and potable water production.

Nitrate-nitrogen is the most common form of nitrogen in fresh water and rarely exceeds $0.1 \mathrm{mg} \mathrm{l}^{-1}$ in natural unpolluted water. This concentration might be enhanced by municipal and industrial waste waters, leachates from waste disposal and from fertilizers. Concentrations between 1.0 and $5.0 \mathrm{mg} \mathrm{l}^{-1}$ which indicate human influences were not observed neither were values greater than 5.0 which usually indicate pollution by human or animal wastes (Chapman, 1996).
Nitrite-nitrogen levels were the least of all the nutrients measured and this was because nitrite-nitrogen concentrations in fresh water are normally very low, usually in the order of 0.001 $\mathrm{mg} \mathrm{l}^{-1}$. The mean value of $0.1 \mathrm{mg} \mathrm{l}^{-1}$ observed at the sites, however, exceeded this value which is indicative of industrial effluents and likely to be associated with poor microbiological quality (Chapman, 1996).

Vollenweider (1970) reported that oligotrophic-mesotrophic lakes had a total phosphate content of $0.008 \mathrm{mg} \mathrm{l}^{-1}\left(8 \mu \mathrm{g} \mathrm{L}^{-1}\right)$ while mesotrophic-eutrophic ones had above $0.017 \mathrm{mg} \mathrm{l}^{-1}(17.6$ $\mu \mathrm{g} \mathrm{l}^{-1}$ ). The average phosphate content of Intake, Galilea and Machigeni stations were in the range of $<0.001-0.893,<0.001-0.282$ and $<0.001$ $-0.326 \mathrm{mg} \mathrm{l}^{-1}$ respectively, and thus fall in the category of eutrophic status. Mean phosphate concentrations ranged from 0.10 to $0.20 \mathrm{mg}$ $\mathrm{I}^{-1} \mathrm{PO}_{4}-\mathrm{P}$ exceeding concentrations in natural unpolluted waters, which range from 0.005 to $0.02 \mathrm{mg} \mathrm{l}^{-1}$. Phosphate availability is generally believed to be a critical factor in eutrophication. Excess phosphate has the potential of causing algae to grow out of control, reducing light and oxygen availability for fish thus compromising the water quality for fish survival, sustenance and growth. The higher nitrite-nitrogen and phosphate levels observed in the reservoir could have enhanced the growth of algae and the corresponding high productivity of the reservoir.

\section{Fish species composition}

The decline in number of species observed from sampling could be attributed to fewer habitat types in the reservoir than in the river with respect to water flow and the non adaptation of some fish to the new lacustrine conditions created by the reservoir resulting in their disappearance or decreased relative abundance with implications for potential fish yield. Quarcoo- 
pome \& Amevenku (2010) reported changes in the Weija Reservoir fish community structure involving shifts in relative abundance of fish based on number, weight and trophic groups. The disappearance of $C$. auratus and the low relative abundance of $O$. niloticus in the Weija Reservoir according to Quarcoopome \& Amevenku (2010) has implications for potential fish yield, reservoir fishery development, and socio-economics of fisher folks since the species are of importance to reservoirs in Ghana.

\section{Potential fish yield}

According to Das et al., (2008), the prime pre-requisite for sound and sustainable fisheries management is to evaluate the fish yield potential of any reservoir for resource planning quantitatively. The objectives of reservoir fishery management are to increase fish yield and to maintain a sustainable harvest of fish at a level near the optimum production of the reservoir. The ability to estimate fish production is very important in permitting managers to make a more accurate appraisal of the expected harvest from reservoirs. The estimated potential fish yield in this study is lower than that reported by Ofori-Danson et al., (1993) due to environmental, anthropological, limnological, and biological factors. The observed decline in PFY in Weija reservoir from $360 \mathrm{t} \mathrm{yr}^{-1}$ or 80.47 $\mathrm{kg} \mathrm{ha}^{-1}$ to $229.45 \mathrm{t} \mathrm{yr}^{-1}$ or $68.27 \mathrm{~kg} \mathrm{ha}^{-1}$ was also observed in the Volta Lake by Ofori-Danson \& Ntow (2005) who reported decline from 32.8 $\mathrm{kg} \mathrm{ha}^{-1}$ in $1974\left(27,880\right.$ tonnes at $\left.8,500 \mathrm{~km}^{2}\right)$ to $29.0 \mathrm{~kg} \mathrm{ha}^{-1}(24,650$ tonnes) in 1995/6 attributed to limnological changes in the reservoir notably increased turbidity.

The estimated PFY of of $68.27 \mathrm{~kg} \mathrm{ha}^{-1}$ for the sampled section of Weija Reservoir is higher than that of $46.21 \mathrm{~kg} \mathrm{ha}^{-1}$ reported for Kpong Headpond (Quarcoopome et al., 2007) which has similar climatic factors. The estimated
Weija PFY is also higher than that for reservoirs in Northern Ghana such as Busunu (2.62 $\mathrm{kg} \mathrm{ha}^{-1}$ ) as well as that of some medium and/or shallow reservoirs in Africa such as Bakolori $\left(50 \mathrm{~kg} \mathrm{ha}^{-1}\right)$ (Ita et al., 1982), Kubani (38 kg ha$\left.{ }^{1}\right)$ (Balogun \& Aduku, 2005), Jebba (40 kg ha-1) in Nigeria (Adeniji 1991). The estimated PFY of Weija Reservoir of $68.27 \mathrm{~kg} \mathrm{ha}^{-1}$ is, however, lower than that of Achubunyo (75.05 kg ha-1), Mahama (90.19 $\mathrm{kg} \mathrm{ha}^{-1}$ ) (Abban et al., 1994), Botanga (86.98 kg ha-1), Libga (97.19 kg ha1) (Quarcoopome et al., 2008) and Oyun Reservoir (125.75 kg ha-1) in Nigeria (Mustapha, 2009). The Weija Reservoir estimated potential fish yield falls within the estimate of $30-150$ $\mathrm{kg} \mathrm{ha}^{-1}$ given by Marshall \& Maes (1994) for managed reservoirs in tropical Africa.

Even though declining compared to previous estimates, the potential fish yield of the sampled section of the Weija Reservoir is still high and could be attributed to the high concentration of dissolved salts, high conductivity, high productivity and low mean depth. The differences in potential fish yield among the sampling stations could be due to differences in physico-chemical, anthropogenic and/or environmental factors.

From this study, PFY is positively and strongly correlated with suspended solids (SS), total dissolved salts (TDS), bicarbonates and alkalinity (Table 4) meaning that as these parameters increase PFY also increases indicating the positive impact of these parameters on PFY. Conversely, PFY is strongly negatively correlated with calcium, chloride, nitrate $\left(\mathrm{NO}_{3}\right)$, nitrite $\left(\mathrm{NO}_{2}\right)$, ammonia $\left(\mathrm{NH}_{3}\right)$, carbonates $\left(\mathrm{CO}_{3}\right)$, calcium hardness, total hardness, flouride, BOD, manganese, and iron (Table 4) meaning that as these parameters decrease PFY increases indicating the inverse nature of the relationship between PFY and these parameters. Similarly for yield, magnesium and mag- 
nesium hardness are positively strongly correlated with PFY while nitrate, iron and BOD are negatively strongly correlated with PFY. Rawson (1952) found a highly significant inverse relationship between fish production and mean depth.

In Latin America, Paiva (1976) identified 10 positive and five negative factors covering both biotic and abiotic parameters influencing fish yield in Brazilian reservoirs. The positive factors were extent of shoreline development, existence and extent of marginal vegetation, tree and brush clearing, average depth of less than $18 \mathrm{~m}$, conditions allowing migration, introduction of pre-adapted lentic fish, existence of permanent fisheries, utilization of modern fishing gears, enforcement of fishery regulations and management and financial assistance to fisheries. The negative factors were erosion of reservoir watershed, reduction of quantity of water flowing into reservoirs, large seasonal water level fluctuation, unbalanced fish population in favour of predatory species and pollution in reservoir watershed. The loss of vegetation through tree and bush clearing for building construction and farming, siltation resulting in declining mean depth and pollution in reservoir watershed are factors evident in the Weija Reservoir. Hence it is important for researchers to take up further study into the effect of these factors.

The high potential fish yield of the Weija Reservoir section sampled suggests that fisheries potential of a medium-sized and low depth reservoir that has reasonably high concentration of dissolved solids, and high conductivity can be more productive than deep reservoirs. This is confirmed by estimates from large deep tropical African reservoirs such as Kariba 60 $\mathrm{kg} \mathrm{ha}^{-1}$ (Machena, 1995), Nasser/Nubia 36 - 39 $\mathrm{kg} \mathrm{ha}^{-1}$ (Rashid, 1995), Kainji 3.5 - $4.7 \mathrm{~kg} \mathrm{ha}^{-1}$ (Balogun \& Ibeun, 1995) and Volta $12 \mathrm{~kg} \mathrm{ha}^{-1}$
(Ryder et al., 1974), all of which are lower than estimates from Weija Reservoir. Also, the high potential fish yield enhanced by the generally good physico-chemical characteristics of the reservoir agrees with the findings of Ranta \& Lindstrom (1998) in Finnish Lakes.

\section{Conclusion}

The physico-chemical characteristics of Weija reservoir are suitable for the growth, survival, and reproduction of fish. The mean fish yield and potential fish yield for the three (3) stations in the southern section of the Weija Reservoir based on morpho-edaphic index show that Machigeni has the highest estimate followed by Intake and Galilea in that order. The mean potential fish yield of $68.27 \mathrm{~kg} \mathrm{ha}^{-1}$ for the southern section of Weija Reservoir based on morpho-edaphic index (MEI) is comparatively high due to high concentration of dissolved solids, high conductivity, high productivity and low mean depth. PFY is positively and strongly correlated with suspended solids (SS), total dissolved salts (TDS), bicarbonates and alkalinity meaning that as these parameters increase PFY also increases indicating the positive impact of these parameters on PFY. Conversely, PFY is negatively correlated with calcium, chloride, nitrate $(\mathrm{NO} 3)$, nitrite $\left(\mathrm{NO}_{2}\right)$, ammonia $\left(\mathrm{NH}_{3}\right)$, carbonates $\left(\mathrm{CO}_{3}\right)$, calcium hardness, total hardness, flouride, BOD, manganese and iron. This means as these parameters decrease PFY increases; an indication of the inverse nature of the relationship between PFY and the parameters.

\section{Recommendations}

To ensure sustainably good catches by fishermen, the reservoir should be managed effectively with the adoption of best management practices (BMP). These management practices include the following: regular monitoring 
of the water quality, quantity, and fish stock; prevention of eutrophication, sedimentation and other watershed abuses that could lead to water quality deterioration and inadequate fish assemblages; enforcement of fishing regulations; control of fish habitat and environmental degradation as well as stocking and/or conservation of desirable and indigenous fish species.

\section{REFERENCES}

Abban, E. K. (1979) Survey of Fish Fauna of Densu River. In: Dassah, A. L. \& Abban, E. K. (eds). Potential for Fishery in the Densu (Weija) Reservoir. Proceedings of a Seminar at CSIR, Accra. pp. $37-41$.

Abban, E. K., Ofori-Danson, P.K. \& Amenvenku, F. K. Y. (1994) Fish and Fisheries of a Reservoir as Index of Fishery and Aquaculture Potential of Reservoirs. In: E. K. Abban, P. K. Ofori-Danson \& C. A. Biney (eds). Fisheries and Aquaculture Development Assessment of Impoundments in West Gonja District, Northern Ghana, Institute of Aquatic Biology, Technical Report No. 136.

Adeniji, H. A. (1991) Limnology and Biological Production in the Pelagic Zone of Jebba Lake, Nigeria. $\mathrm{Ph}$.D. Thesis, University of Ibadan.

Ameka, G. K., de-Graft-Johnson, K. A. A. \& Akuamoah, R. K. (2000) A Review of Chemical Status of the Weija Lake. J. of the Ghana Science Association 2 (2), 136 - 147.

Amevenku, F. K. Y. \& Quarcoopome, T. (2006) Fish and Fisheries of Bontanga Reservoir in Northern Ghana. West African Journal of Applied Ecology 10, $9-19$.

Ansa-Asare, O. D. \& Asante, K. A. (1998) A Comparative Study of the Nutrient Status of Two Reservoirs in South-East Ghana. Lakes and Reservoirs: Research and Management 3, 205 - 217.

APHA-AWWA-WEF (2005) Standard Methods for the Examination of Water and Waste Water (21st ed.). American Public Health Association, American Water Works Association and Water Environment Federation, Washington, D.C.

Balogun, J. K. \& Aduku, U. J. (2005) Predicting the Fisheries Potentials of Inland Reservoirs and Lakes: a Case Study of Kubanni Reservoir, Ahmadu Bello University, Zaria. In: 19th Annual Conference of the Fisheries Society of Nigeria (FISON), 29 Nov - 03 Dec 2004, Ilorin, Nigeria. pp. $844-850$.

Bank of Ghana (2008) Bank of Ghana Annual Report.

Barry, B., Obuobie, E., Andreini, M., Andah, W. \& Pluquet, M. (2005) The Volta River Basin Comprehensive Assessment of Water Management in Agriculture. Comparative study of River Basin Development and Management. IWMI, Colombo.

Bhukaswan, T. (1980) Management of Asian Reservoir Fisheries. FAO Fish. Tech. Pap., (207). pp. 69.

Boyd, C. E. (1982). Water Quality Management for Pond Fish Culture. Elsevier Scientific Pub. Co., Nature. pp. 318 .

Braimah L. I. (2000) Full Frame Survey at Volta Lake, Ghana, 1998. Fisheries Subsector Capacity Building Project. IDAF Project, Yeji. pp. 196.

Braimah L. I. (2003) Fisheries Management Plan for the Volta Lake. Report for the Ministry of Food and Agriculture, Directorate of Fisheries, Accra, Ghana. pp. 81.

Carlander, K. D. (1955) The Standing Crops of Fish in Lakes. Journal of the Fisheries Research Board of Canada 12 (4) 543 - 570.

Chapman, D. V. (ed. 1996) Water Quality Assessments: A guide to use Biota, Sediments and Water. Environmental Monitoring. Second Edition. UNESCO, WHO, and UNEP. E \& FN Spon, London UK. 
Cooper, M., Lewis, S. E. \& Smithers, S. G (2016) Spatial and temporal dynamics of suspended sediment causing persistent turbidity in a large reservoir: Lake Dalrymple, Queensland, Australia. Marine and Freshwater Research 68, 1377 -1390 .

Dankwa, H. R., Abban, E. K. \& Teugels, G. G. (1999) Freshwater Fishes of Ghana: Identification, Distribution, Ecological and Economic Importance. Annales des Sciences Naturelles.

Das, A. K., Shrivastava, N. P., Vass, K. K. \& Pandley, B. L. (2008) Management Strategies for Enhancing Fish Production in Madhya Pradesh Reservoirs. In: Sengupta, M \& Dalwani, R. (eds). Proceedings of $12^{\text {th }}$ World Lake Conference. pp. $1295-1300$.

Dassah, A. L. \& Abban, E. K. (eds) (1979) Potential for Fishery in the Densu (Weija) Reservoir. Proceedings of a Seminar by CSIR, Accra. pp. 72.

Dugan, P. (2003) Investing in Africa: The WorldFish Centre's African Strategy in Summary. NAGA, WorldFish Centre Quarterly 26 (3), 3 - 8.

Elegbede, I. O., Kies, F., Omolara, L. A. A., Rashidat, s. d., Hakeem, F-B., Latunji, A. S., Zaid, A. A., Emeka, N., Charles, O. I. \& Oluwaseun, F. (2015) Effect of Water Quality Characteristics on Fish Population of the Lake Volta, Ghana. J. Environ. Anal. Toxicol. 5, 317. doi:10.4172/21610525.1000317

Fernando, C.H., Gurgel, J. J. S. \& Moyo, N. A. G. (1998) A Global View of Reservoir Fisheries. Internationale Revue der Gesamten Hydrobiologie $\mathbf{8 3}, 31-42$.

Henderson, H. F. \& Welcomme, R. L. (1974) The Relationship of Yield to Morpho-edaphic Index and Numbers of Fishermen in African Inland Fisheries. Food and Agriculture Organization of the United Nations, CIFA Occasional Paper 1, Rome, Italy. pp. 19.

Idowu, R. T., Inyang, N. M. \& Eyo, J. E. (2004) The Physico-Chemical Parameters of an African Arid
Zone Man Made Lake. Animal Research International 1 (2), 113 - 119.

Ita, E. O, Eyo, A. A. \& Mohammed, A. (1982) An Experimental Pilot Fisheries Development Project at Shagamu and Monia, Kainji Lake Research Institute, Annual Report 27 - 31.

Janjua, M. Y, Ahmad, T. \& Gerdeaux, D. (2008) Comparison of Different Yield Predictive Models for Estimating Fish Yields in Shahpur Dam, Pakistan. Lakes and Reservoirs: Research and Management 13, 319 - 324.

Jenkins, R. M. (1982) The Morpho-edaphic Index and Reservoir Fish Production. Transactions of the American Fisheries Society 111, 133 - 140.

Jhingran, A. G. (1991) Performance of Tilapia in Indian Waters and its Possible Impact on the Native Ichthyofauna. IPFC Proceedings, Bogor, Indonesia, 24-29 June, 1991. FAO Fisheries Report No. 458, FAO, Rome. pp. $143-161$.

Kantoussan, J., Ecoutin, J. M., Fontenelle, G., Morais, L. T. \& Lae, R. (2014) Catch Per Unit Effort and Yields as Indicators of Exploited Fish Communities: Application to Two West African Reservoirs. Lakes and Reservoirs: Research and Management. 19, $86-97$.

Kolding, J. \& van Zwieten, P. A. M. (2006) Improving Productivity in Tropical Lakes and Reservoirs. Challenge Programme on Water and Food. Aquatic Ecosystems and Fisheries Review Series 1, Cairo: WorldFish Centre.

Lévêque, C. (1999) Les poisons des eaux continentals africaines: diversité, écologie, utilisation par l'homme. IRD, Paris. pp. 521 .

Machena, C. (1995) Recent Developments in the Fisheries of Lake Kariba (Zambia/Zimbabwe). In: Current Status of Fisheries and Fish Stocks of the Four Largest African Reservoirs: Kainji, Kariba, Nasser/Nubia and Volta (eds. R. C. M. Crul and T. C. Roest). CIFA Tech. Pap. No 30, FAO, Rome. pp $41-79$. 
Mallya, J. Y. (2007) The Effects of Dissolved Oxygen on Fish Growth in Aquaculture. UNU-Fisheries Training Programme.

Marshall, B. E. (1984) Towards Predicting Ecology and Fish Yields in African Reservoirs from Pre-impoundment Physico-chemical Data. CIFA Tech. Pap., (12). pp. 36. Rome: FAO.

Marshall, B. E. \& Naes, M. (1994) Small Water Bodies and their Fisheries in Southern African. CIFA Technical Paper No. 29, Rome, FAO. pp. 68.

Miranda, L. E. (1999) A Typology of Fisheries in Large Reservoirs of the United States.In: North American Journal of Fishery Management 19, $536-550$.

Moreau, J. \& De Silva, S. S. (1991) Predictive Fish Yield Models for Lakes and Reservoirs of the Philippines, Sri Lanka and Thailand. FAO Fish. Tech. Pap. No 319, Rome, Italy.

Mustapha, M. K. (2009) Limnological Evaluation of the Fisheries Potentials and Productivity Of a Small Shallow Tropical African Reservoir. Rev. Biol. Trop. (Int. J. Trop. Biol. ISSN-00347744) 57 (4), 1093 - 1106.

Ofori-Danson, P. K., Abban, E. K. \& Amevenku, F. K. Y. (1993) Status of Fish and Fishery in the Densu-Weija Reservoir Fourteen years after Impoundment. Institute of Aquatic Biology Technical Report 128.

Ofori-Danson, P. K. \& Ntow, W. J. (2006) Studies on the Current State of the Limno-chemistry and Potential Fish Yield of Lake Volta (Yeji sector) after Three Decades of Impoundment. Ghana J. Agric. Sci. 35, $65-72$.

Oglesby, R. T. (1977) Relationships of Fish Yield to Lake Phytoplankton Standing Crop, Production, and Morpho-edaphic Factors. Journal of the Fisheries Research Board of Canada 34, 2271 2279.

Paiva, M. P. (1976) Estimativa do potential da produçaõ de pescado em grandes represas Brasileiras.
Diretoria de Coordenaçaõ, Electrobras Centrais Eléctricas Brasileiras S.A., Rio de Janeiro - RJ Brasil. ppp. 23 .

Paugy, D., Leveque, C. \& Teugels, G. G. (2003a) The Fresh and Brackish Water Fishes of West Africa. Vol I. Publications Scientifiques du Museum, MRAC. pp. 457.

Paugy, D., Leveque, C. \& Teugels, G. G. (2003b) The Fresh and Brackish Water Fishes of West Africa. Vol II. Publications Scientifiques du Museum, MRAC. pp. 815.

Quarcoopome, T. \& Amevenku, F. K. Y. (2006) Status of the Fish Fauna of Weija Reservoir.W.R.I. Technical Report.

Quarcoopome, T., Amevenku, F. K. Y., Asante, K. A. \& Akpabey, F. J. (2007) Ecology and Socio-economics of Kpong Headpond - 25 Years After Impoundment. CSIR-WRI Technical Report No 136, Accra, Ghana.

Quarcoopome, T., Amerenku, F. Y. K. \& AnsaAsare, O. D. (2008) Fisheries and Limnology of Two Reservoirs in Northern Ghana. West Africa. J. Appl. Ecol. 12, $61-80$.

Quarcoopome, T. \& Amevenku, F. K. Y. (2010) Fish Community Structure of Weija Reservoir After 28 Years of Impoundment. Journal of Applied Science \& Technology 15 (1\&2), $126-131$.

Quarcoopome, T. \& Amevenku, F. K. Y. (2010) Fish and Fisheries of Kpong Headpond - 25 Years after Impoundment. West Africa. J. Appl. Ecol. 16, $51-63$.

Ranta, E. \& Lindstrom, K. (1998) Fish Yield versus Variation in Water Quality in the Lakes of Kuusamo, Northern Finland. Annales Zooloigici Fennici 35, $95-106$.

Rashid, M. M. (1995) Some Additional Information on Limnology and Fisheries of Lake Nasser (Egypt) and Nubia (Sudan). In: Current Status of Fisheries and Fish Stocks of the Four Largest African Reservoirs: Kainji, Kariba, Nasser/Nu- 
bia and Volta (eds R. C. Crul and F. C. Roest). CIFA Technical Paper No. 30, FAO, Rome. pp. $81-109$.

Rawat, H. S. (1991) Studies on the Limnology and Fisheries of Tumaria Reservoir (Nainital).

Ph.D. Thesis, Kumaun University, Nainital. pp. 188.

Rawson, D. S. (1952) Mean Depth and the Fish Production of Large Lakes. Ecology 33, 513 - 521.

Regier, H. A., Cordone, A. J. \& Ryder, R. A. (1971) Total Fish Landings from Fresh Water as a Function of Limnological Variables with Special Reference to Lakes of East Central Africa, Food and Agriculture Organization of the United Nations FL: SF/GHA10. Fish Stock Assessment Working Paper 3, FAO, Rome.

Ryder, R. A. (1965) A Method for Estimating the Potential Fish Production of North Temperate Lakes. Transactions of the American Fisheries Society 94, $214-218$.

Ryder, R. A., Kerr, S. R., Loftus, K. H. \& Regier, H. A. (1974) The Morpho-edaphic Index, a Fish Yield Estimator - Review and Evaluation. Journal of Fisheries Research Board Canada 31, 663 -688 .

Sarma, B. C. (1990) Keynote address. National Workshop on Reservoir Fisheries, 3 - 4 January, 1990. Central Inland Capture Fisheries Research Institute, Barrackpore, India.

Schlesinger, D. A. \& Regier, H. A. (1982) Climatic and Morpho-edaphic Indices of Fish Yields from Natural Lakes. Transactions of the American Fisheries Society 111, 141 - 150.
Sreenivasan, P. V. (1978) Observations on the Fishery and Biology of Megalaspis cordyla (Linnaeus) at Vizhinjam, ibid 25 (1 \& 2), 122 - 146.

Srivastava, U. K., Desai, D. K., Gupta, V. K., Rao, S. S., Gupta, G. S., Raghavachari, M. \& Vatsala, S. (1985) Inland Fish Marketing in India Reservoir Fisheries Concept Publishing Co., New Delhi 4(A\&B), (A) 403p \& (B)1184p.

Sugunan, V. V. (1995) Reservoir Fisheries in India. FAO Fish. Tech. Pap. No. 345. Rome. pp. 423.

Talling, J.F. (2010) Potassium - a non-limiting nutrient in freshwater? Freshwater Reviews. Freshwater Biology Association. 3, 97 - 104.

Tom, L. (1998) Nutritional and Feeding of Fish. Kluwer Academic Publishers. Second Edition.

Vanden Bossche J.-P \& Bernacsek, G. M. (1990) Source Book for the Inland Fishery Resources of Africa. Vol (1) CIFA Tech. Pap. No 18/1. pp. 240.

Vollenweider, R. A. (1970) Scientific Fundamental of the Eutrophication of Lakes and Flowing Waters with Particular Reference to Nitrogen and Phosphorus as Factors in Eutrophication. Organization for Economic Co-operation and Development, Paris, France.

Wadjowicz, Z. (1964) The Development of Ichthyofauna in Dam Reservoirs with Small Variations in Water Level. Acta Hydrobiol. 6 (1), 61 - 79.

Welcomme, R. L. (1974) Some General and Theoretical Considerations on the Fish Production of African Rivers. CIFA Occas. Pap. (3). pp. 26. 